\title{
A comparison of the treatment results of open reduction internal fixation and intramedullary nailing in adult forearm diaphyseal fractures
}

\author{
Ahmet Köse, M.D., ${ }^{1}$ Ali Aydın, M.D., ${ }^{2}$ Naci Ezirmik, M.D., ${ }^{2}$ Ömer Selim Yıldırım, M.D. ${ }^{2}$ \\ ${ }^{1}$ Department of Orthopedics, Erzurum Regional Training and Research Hospital, Erzurum-Turkey \\ ${ }^{2}$ Department of Orthopedics and Traumatology, Atatürk University Faculty of Medicine, Erzurum-Turkey
}

\begin{abstract}
BACKGROUND: We compared the union and functional results of intramedullary nailing and open reduction internal fixation treatment applied to adults with a forearm diaphysis fracture (fracture of the radius and/or ulna).

METHODS: We retrospectively examined 90 patients with completed skeletal maturation who were surgically treated for a forearm diaphyseal fracture. Patients with a Monteggia Galeazzi and ipsilateral upper extremity fracture and those with an open epiphyseal line, Type 3 open fracture, pathological fracture, or brain trauma were excluded from the study. Open reduction and internal fixation (ORIF) was applied to 42 patients (plate group), and intramedullary nailing was performed in 48 patients (intramedullary nailing group). Both treatment groups were compared with respect to time to union, joint range of motion, operating time, grip strength, Grace-Eversman criteria, and complications.
\end{abstract}

RESULTS: The mean operating time was 63.29 (range, 40-100) min in the plate group and 46.02 (range, 17-85) min in the intramedullary nailing group. The mean time to union was 13.19 (range, 10-20) and 10.85 (range, 8-20) weeks, respectively. While a statistically significant difference was determined between groups with respect to operating time and time to union, no difference was determined in the Grace-Eversman evaluation criteria, forearm supination, pronation degrees, and grip strength.

CONCLUSION: The results of this study showed a significant difference in the intramedullary nailing treatment with respect to time to union, operating time, and amount of bleeding compared with the ORIF treatment. However, no difference was determined in the functional evaluation criteria. Thus, both treatment methods are acceptable in the treatment of forearm diaphyseal fractures in adults with skeletal maturation.

Keywords: Forearm; internal fixation; intramedullary nail; open reduction.

\section{INTRODUCTION}

Forearm supination and pronation movements are initiated from the proximal and distal radioulnar joints. Therefore, the radius and ulna have an important role in the movement of not only the forearm but also the whole upper extremity. Treatment of forearm fractures with insufficient or inappro-

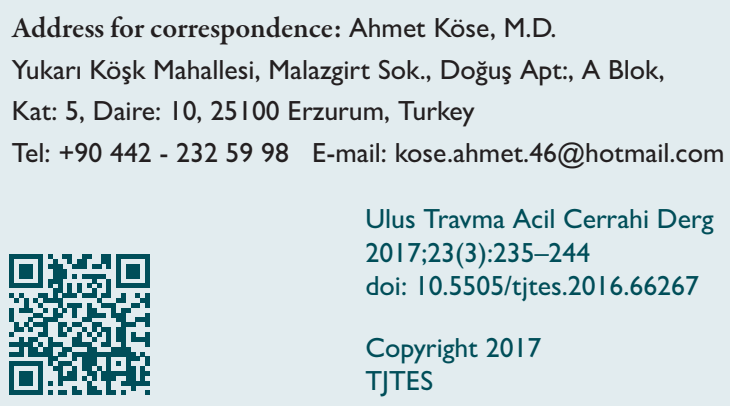

priate implants restricts forearm rotation. Simultaneously, wrist and elbow joint movements are affected negatively. Due to functional and anatomic features, forearm diaphyseal fractures are different from diaphyseal fractures of other long bones and must be evaluated as intraarticular fractures, with treatment planned accordingly. ${ }^{[1,2]}$

Conservative methods are not recommended for these fractures, which are relatively rare in adults. ${ }^{[3]}$ The deforming effect of muscle strength, continuity of the radial incline, and intraosseous membrane damage are significant factors that affect the stabilization and maintenance of a reduction. ${ }^{[4]}$ It is almost impossible to achieve sustainable and stable fixation with conservative treatment. The basic aim of treatment is to provide axial alignment and rotational stability. Open reduction and internal fixation (ORIF) is a widely used and accepted treatment method that is associated with high rates of union and satisfactory functional results. However, open application of the method has attracted some criticism. Problems such 
as cosmetic issues, drainage of the fracture hematoma, the risk of soft tissue and periosteal damage, and skin irritation of implants, particularly in ulnar fractures, have been reported. The criticized aspects of ORIF have made it controversial as a standard treatment method. Along with traditional treatments for forearm diaphyseal fractures, an ongoing search for an alternative treatment method is being conducted. Generally, nonspecific intramedullary (IM) implants have been used as an alternative treatment method. Because they do not have locking and compression features, these materials cause high rates of nonunion; therefore, their use has been abandoned. Current IM forearm nails have emerged with locking and compression features. The use of this method in treatment is increasing with union rates similar to those of ORIF and very good functional results. ${ }^{[5-8]}$

In this study, we conducted a retrospective examination of adults who underwent ORIF and IM nailing for forearm di- aphyseal fractures. We compared the two treatment methods with respect to union status, functional and radiological results, and patient satisfaction.

\section{MATERIALS AND METHODS}

We conducted a retrospective evaluation of adults with complete skeletal maturation who underwent ORIF or IM nailing because of an isolated fracture of the ulna and/or radius. Approval for the study was granted by the Institutional Review Board. Written informed consent was obtained from all patients. A total of 130 patients treated between 2008 and 2014, with at least I year of follow-up, were contacted by telephone and invited to attend the hospital. Of $110 \mathrm{pa}-$ tients who accepted the invitation, 90 met the criteria for inclusion in the study, which was conducted at a single center. Two surgeons performed ORIF and two performed IM nailing.

Table I. Patients' medical information and demographic distribution

\begin{tabular}{|c|c|c|}
\hline & Plate group & Intramedullary nail group \\
\hline Number of patients & 42 & 48 \\
\hline \multicolumn{3}{|l|}{ AO/OTA fracture type, $n$ (\%) } \\
\hline $\mathrm{Al}$ & $6(14.3)$ & $8(16.7)$ \\
\hline $\mathrm{A} 2$ & $5(11.9)$ & $6(12.5)$ \\
\hline A3 & $4(9.5)$ & $4(8.3)$ \\
\hline $\mathrm{BI}$ & $7(16.7)$ & $8(16.7)$ \\
\hline B2 & $5(11.9)$ & $4(8.3)$ \\
\hline B3 & $3(7.1)$ & $3(6.25)$ \\
\hline $\mathrm{Cl}$ & $6(14.3)$ & $9(18.75)$ \\
\hline $\mathrm{C} 2$ & $4(9.5)$ & $4(8.3)$ \\
\hline $\mathrm{C} 3$ & $2(4.8)$ & $2(4.2)$ \\
\hline \multicolumn{3}{|l|}{ Fractured forearm, n (\%) } \\
\hline Right & $19(45.2)$ & $28(58.3)$ \\
\hline Left & $23(54.8)$ & $20(41.7)$ \\
\hline Closed fracture, n (\%) & $34(8 I)$ & $36(75)$ \\
\hline Type I-2 open fracture, n (\%) & $8(19)$ & $12(25)$ \\
\hline \multicolumn{3}{|l|}{ Gender distribution, n (\%) } \\
\hline Female & $28(66.7)$ & $14(33.3)$ \\
\hline Male & $37(77.1)$ & II (22.9) \\
\hline \multicolumn{3}{|l|}{ Trauma etiology, n (\%) } \\
\hline Traffic accident & $15(35.7)$ & $26(54.16)$ \\
\hline Fall & $10(23.8)$ & $9(18.75)$ \\
\hline Work injury & $5(I 1.9)$ & $4(8.33)$ \\
\hline Sports injury & $9(21.4)$ & $6(12.50)$ \\
\hline Assault & $3(7.1)$ & $3(6.25)$ \\
\hline Average age & $38.02(18-65)$ & $36.6(18-63)$ \\
\hline Follow-up period, avg. (week) & $70(65-150)$ & $55.49(52-170)$ \\
\hline
\end{tabular}

AO/OTA: Arbeitsgemeinschaft für Osteosynthesefragen/Orthopaedic Trauma Association Classification. 
Patients with a Monteggia Galeazzi, an open epiphyseal line, Type 3 open fracture, pathological fracture, an insufficient follow-up period, or brain trauma were excluded from the study. Patients with a Type I-2 open fracture were admitted for emergency surgery after sufficient irrigation had been applied.

ORIF was performed in 42 patients (plate group) and IM nailing in 48 (IM nailing group). Fractures were classified according to the Arbeitsgemeinschaft für Osteosynthesefragen/ Orthopaedic Trauma Association Classification (AO/OTA) ${ }^{[0]}$ system. In the plate group, 15 (35.7\%) fractures were Type A, 15 (35.7\%) were Type B, and 12 (28.6\%) were Type C, as compared with 18 (37.5\%), I5 (3I.25\%), and I5 (3I.25\%), respectively, in the IM nailing group (Table I). The limited contact dynamic compression plate (LC-DCP) was used in plate osteosynthesis, and newly designed radius and ulnar screws were used in IM fixation.

Union was evaluated radiologically as bridge callus formation or the absence of a fracture line and clinically as lack of pain on the fracture line. Nonunion was considered when no bridge callus formation was observed after 6 months of follow-up. Functional results and union evaluation were made according to the Grace-Eversman ${ }^{[10]}$ criteria. Patient satisfaction was evaluated with the Disabilities of the Arm, Shoulder, and Hand $(\mathrm{DASH})^{[1 !]}$ questionnaire on the basis of physical activity in the previous week and satisfaction level. In patients with fracture of the radius and fractures of both bones, the maximum radial incline (MRI) and maximum radial incline localization (MRIL) were measured ${ }^{[3]}$ (Fig. I).

Joint range of movement was evaluated goniometrically. With the elbow in $90^{\circ}$ flexion, the forearm pronation and supination angles were measured. Grip strength was measured with a hydraulic hand dynamometer (SAEHAN Hydraulic Hand Dynamometer [SH500I], Gyeongnam, South Korea). With the patient in a sitting position, the shoulder neutral in abduction, the forearm and wrist neutral, and the elbow in $90^{\circ}$ flexion, separate measurements were taken of the treated and healthy forearms.

Patients' preoperative demographic information and postoperative follow-up data were obtained from the hospital database. Data related to operating time, amount of blood loss, fluoroscopy time, and complications were obtained from the surgical records. Radiological data were evaluated using the radiographs taken at the 6-month follow-up examination. Union was evaluated on AP, lateral, and oblique radiographs. Callus formation in four cortices was evaluated as union. The Grace-Eversman criteria, joint range of motion (ROM) measurements, and grip strength measurements were obtained for all patients from the postoperative 6-month data. The DASH questionnaire was applied and scored at the final follow-up examination.

\section{Surgical Technique}

All patients were treated within $1-5$ days of presentation; mean 1.67 (range, I-5) days in the plate group and 17.42 (range, 6-48) h in the IM nailing group. All patients received I g cefazolin intravenously at 30 min preoperatively. For the application of IM nailing, the patients were positioned in a supine position on a radiolucent operating table. A tourniquet was applied in the ORIF operations but not in the IM method.

Operations on patients with a forearm double fracture were started from the ulna. Closed reduction was attempted under fluoroscopy on all fractures before starting the application of IM nailing. With the forearm in a neutral position, a $2-\mathrm{cm}$ longitudinal skin incision was made from the most prominent point of the olecranon while the elbow was in $90^{\circ}$ flexion. A 2-mm-thick K-wire was advanced IM from a point $6.5 \mathrm{~mm}$ proximal and $3 \mathrm{~mm}$ lateral to the most prominent point of the olecranon. ${ }^{\left[{ }^{[2]}\right]}$ After drilling IM for $5 \mathrm{~cm}$ proximally with a cannulated drill over the K-wire, the prepared nail was advanced as far as the fracture line with partial rotation. In patients where fixation was obtained with closed reduction, the nail was advanced as far as the most distal point. In patients where closed reduction could not be achieved, fixation was obtained with partial open reduction from the fracture line. The forearm was positioned neutrally with distal and proximal locking. In fractures requiring static locking, double cortex distal locking was applied with a sufficient number of 3-mm cortical screws. Depending on the fracture stability status from the proximal, single cortex locking was performed, or compression was applied (Fig. 2a).

For radial fractures, a $\mathrm{I}-1.5-\mathrm{cm}$ longitudinal skin incision was made at least $\mathrm{I} \mathrm{cm}$ proximal to the distal joint space from the

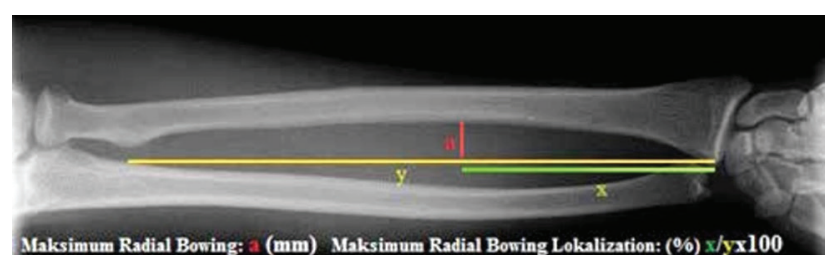

Figure 1. Measurement of radial inclination and maximum radial inclination localization in subjects with radial fractures. (A) Radial inclination $(\mathrm{mm}), \mathrm{x} / \mathrm{y} \times 100=$ Maximum radial inclination localization $(\%)$

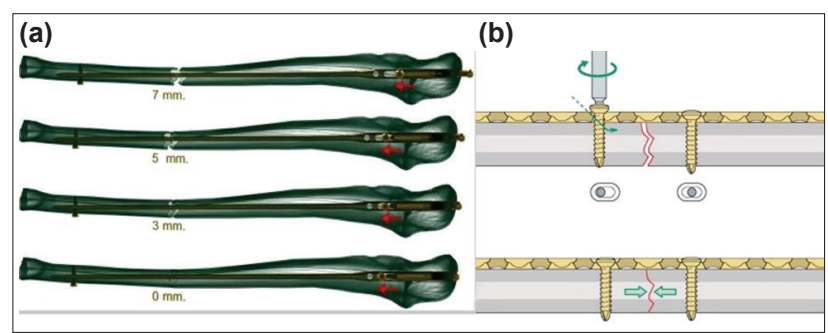

Figure 2. View of the ulna intramedullary nail compression applications up to $7 \mathrm{~mm}$ at the proximal of the ulna (a), view of the LC-DCP compression applications (b). 
lateral aspect of the distal metaphysis (Lister tubercle lateral). The extensor carpi radialis longus and brevis (ECRB) tendons were located. The ECRB tendon sheath was opened longitudinally with a blunt dissection. The first entry into the second extensor compartment was made with an awl perpendicular to the radial metaphysis. The first entry area was widened by targeting the medullar cavity with a curved awl. A nail of specified appropriate length and diameter was advanced with a nail holder with partial rotational forces. When the tip of the nail reached the fracture line, we checked whether the nail had been advanced intramedullarly using fluoroscopy. It was advanced until a final push achieved full contact of the nail with the distal radial metaphyseal cortex. Static distal locking was applied. Newly designed radius and locking ulna screws were used as IM fixation material (TST Rakor Tıbbi Aletler San. ve Tic. Ltd. Sti., Istanbul, Turkey).

For the plate application, the volar Henry incision was used in distal and mid third radius fractures, and the Thompson approach was used for proximal third fractures. For ulnar

Table 2. Comparison of post treatment and surgery data of patients in the plate and IM nail groups

\begin{tabular}{|c|c|c|c|c|c|c|}
\hline & Plate group & SD & $\mathbf{p}$ & IM nail group & SD & $\mathbf{p}$ \\
\hline Fluoroscopy period (minute), avg. (range) & 0 & - & & $1.2(0.2-5)$ & 0.55 & \\
\hline Surgery period (minute), avg. (range) & $63.29(40-100)$ & 14.3 & 0.001 & $46.02(17-85)$ & 23.8 & 0.001 \\
\hline Union period (week), avg. (range) & $13.19(10-20)$ & 2.65 & 0.01 & $10.85(8-20)$ & 2.66 & 0.01 \\
\hline AO/OTA Tip AI & $13.00(12-20)$ & 8.00 & 0.17 & $10.16(8-12)$ & 2.00 & 0.05 \\
\hline AO/OTA Tip A2 & $14.2(12-20)$ & 10.00 & 0.21 & $9.3(8-12)$ & 4.00 & 0.10 \\
\hline AO/OTA Tip A3 & $14.25(10-20)$ & 6.00 & 0.13 & $11.25(11-12)$ & 3.00 & 0.07 \\
\hline AO/OTA Tip BI & $13.14(12-16)$ & 8.00 & 0.17 & II.75(8-20) & 4.00 & 0.10 \\
\hline AO/OTA Tip B2 & $12.2(10-14)$ & 4.00 & 0.08 & $10(8-12)$ & 3.00 & 0.07 \\
\hline AO/OTA Tip B3 & $12.33(11-16)$ & 7.00 & 0.15 & $10.33(8-11)$ & 3.00 & 0.07 \\
\hline AO/OTA Tip Cl & $12.5(|1-| 4)$ & 2.00 & 0.04 & II.44 (8-20) & 9.00 & 0.21 \\
\hline AO/OTA Tip C2 & $14.00(10-20)$ & 1.00 & 0.02 & $13.75(10-20)$ & 8.00 & 0.19 \\
\hline AO/OTA Tip C3 & $12.00(11.13)$ & 2.00 & 0.04 & $14.00(12-16)$ & 6.00 & 0.14 \\
\hline \multicolumn{7}{|l|}{ Post Follow up ROM (degree) (avg.) (range) } \\
\hline Supination & $74.64(65-80)$ & 4.07 & 0.631 & $75.06(65-80)$ & 3.75 & 0.631 \\
\hline Pronation & $84.55(64-90)$ & 4.27 & 0.645 & $84.92(74-90)$ & 4.15 & 0.645 \\
\hline DASH score, avg. (range) & $9.81(3.3-30)$ & 6.72 & 0.63 & $12.87(3.3-38.8)$ & 8.65 & 0.63 \\
\hline \multicolumn{7}{|l|}{ Grace-Eversman ratio $(n, \%)$} \\
\hline Perfect & $36(85.7 \%)$ & & & 40 (83.3\%) & & \\
\hline Good & $4(9.5 \%)$ & & & $8(16.7 \%)$ & & \\
\hline Acceptable & I $(2.4 \%)$ & & & & & \\
\hline Not acceptable & I (2.4\%) & & & & & \\
\hline Grip strength (kgw), avg. (range) & $60.02(30-115)$ & 22.5 & 0.731 & $55.21(30-110)$ & 17.2 & 0.731 \\
\hline Bleeding during surgery (ml), avg. (range) & $84.04(40-250)$ & 59.3 & 0.000 & $37.91(10-100)$ & 30.2 & 0.000 \\
\hline Complication ratio & $3(7.1 \%)$ & & & $2(4.16 \%)$ & & \\
\hline \multicolumn{7}{|l|}{ Elbow joint ROM (degree) (avg.) (range) } \\
\hline Flexion & $142.36(133-145)$ & 3.6 & 0.519 & $142.63(132-145)$ & 3.5 & 0.519 \\
\hline Extension & $0.67(0-5)$ & 1.5 & 0.683 & $0.75(0-5)$ & 1.55 & 0.683 \\
\hline \multicolumn{7}{|l|}{ Wrist joint ROM (degree) (avg.) (range) } \\
\hline Dorsiflexion & $78.57(75-80)$ & 1.79 & 0.009 & $78.31(74-80)$ & 1.9 & 0.009 \\
\hline Volar flexion & $75.07(73-80)$ & 0.83 & 0.514 & $74.46(7 I-80)$ & 1.8 & 0.514 \\
\hline \multicolumn{7}{|l|}{ Radiological Evaluation, avg. (range) } \\
\hline MRI & $13.74(\mid 2.5-16.67)$ & 0.9 & 0.231 & $13.36(10-14.9)$ & 0.93 & 0.231 \\
\hline MRIL & $57.29(53-6 \mid .5)$ & 2.38 & 0.138 & $58.04(49-65.5)$ & 3.61 & 0.138 \\
\hline
\end{tabular}

IM: Intramedullary; SD: Standard deviation; AO/OTA: Arbeitsgemeinschaft für Osteosynthesefragen/Orthopaedic Trauma Association Classification; ROM: Range of motion; DASH: Disabilities of the Arm, Shoulder and Hand; MRI: Maximum radial incline; MRIL: Maximum radial incline localization. 

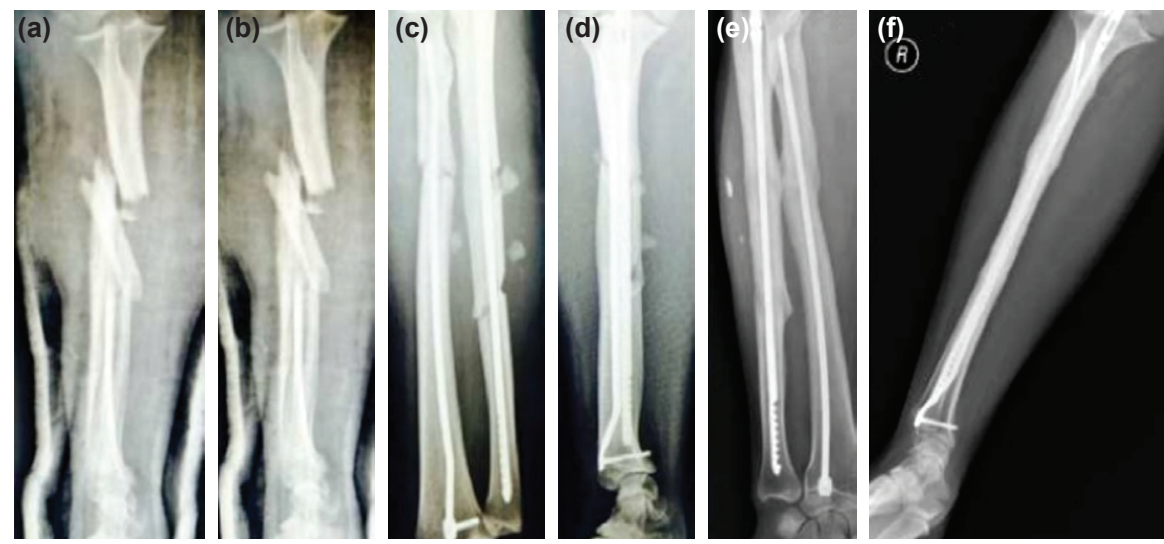

Figure 3. AP and lateral radiographs (a, b) Type 22C1 fracture on the right radius and ulna diaphysis belonging to a 32-year-old male patient after in vehicle traffic accident. The patient's second month $(\mathbf{c}, \mathbf{d})$ and $12^{\text {th }}$ month $(\mathbf{e}, \mathbf{f})$ direct radiographs.

fractures, a transcutaneous incision was made. ${ }^{[l]}$ The fracture line was reached with controlled surgical dissection and control of bleeding. Care was taken not to strip the periosteum excessively. The plate used as fixation material was a 3.5-mm LC-DCP. A plate of appropriate size was selected according to the fracture type and degree of fragmentation. We applied compression AO principles based on the fracture line (Fig. 2b). Fixation was made with a minimum of three screws holding at least six cortices distal and proximal to the fracture line. Following fixation and bleeding control, an aspirative drain was placed in the surgical area. The drain was removed on postoperative day 2 . No graft was used in the primary surgery of any patient in either the plate or IM group. In patients who underwent IM nailing, early-stage ROM exercises were started without immobilization. In the plate group, ROM exercises were started following 2 weeks of splint immobilization.

\section{Statistical Methods}

In the data analyses, SPSS v.20 computer software was used. Data were stated as number, percentage, mean, and standard deviation. Conformity of the data to the normal distribution for the variables included in the analysis was analyzed with the Kolmogorov-Smirnov test. Spearman's correlation analysis was used to evaluate the correlation between parameters. Nonparametric data on the plate and IM nailing groups were compared by means of the Mann-Whitney U-test. Parametric data were analyzed with the Student's t-test. A value of $p<0.05$ was accepted as statistically significant.

\section{RESULTS}

Fractures were in the right extremity in 19 (45.2\%) patients and in the left in $23(54.8 \%)$ in the plate group, compared with $28(58.3 \%)$ and $20(41.7 \%)$, respectively, in the IM nailing group. The etiology of the fractures was a traffic accident in I5 (35.7\%) cases, a fall in 10 (23.8\%), a sporting injury in 9 $(21.4 \%)$, an industrial accident in 5 (11.9\%), and impact in 3 (6.25\%; Table I).
There were $16(38.1 \%)$ patients with a fracture of both bones, $14(33.3 \%)$ with a radial fracture, and $12(28.6 \%)$ with an ulnar fracture in the plate group, compared with 18 (37.5\%), 15 (31.25\%), and 15 (31.25\%), respectively, in the IM nailing group. According to the Gustilo-Anderson ${ }^{[13]}$ open fracture classification, 8 (19\%) patients in the plate group and $12(25 \%)$ patients in the IM group had Type I-2 open fractures.

The mean time to union was 13.19 (range, 10-20) weeks in the plate group and 10.85 (range, 8-20) weeks in the IM nailing group (Table 2). A statistically significant difference was determined between the two groups $(p<0.05)$. Bone union was achieved at $100 \%$ in the IM nailing group and at $97.6 \%$ in the plate group (Fig. 3, 4). Mean operating time was 63.29 (range, 40-100) $\mathrm{min}$ in the plate group and 46.02 (range,
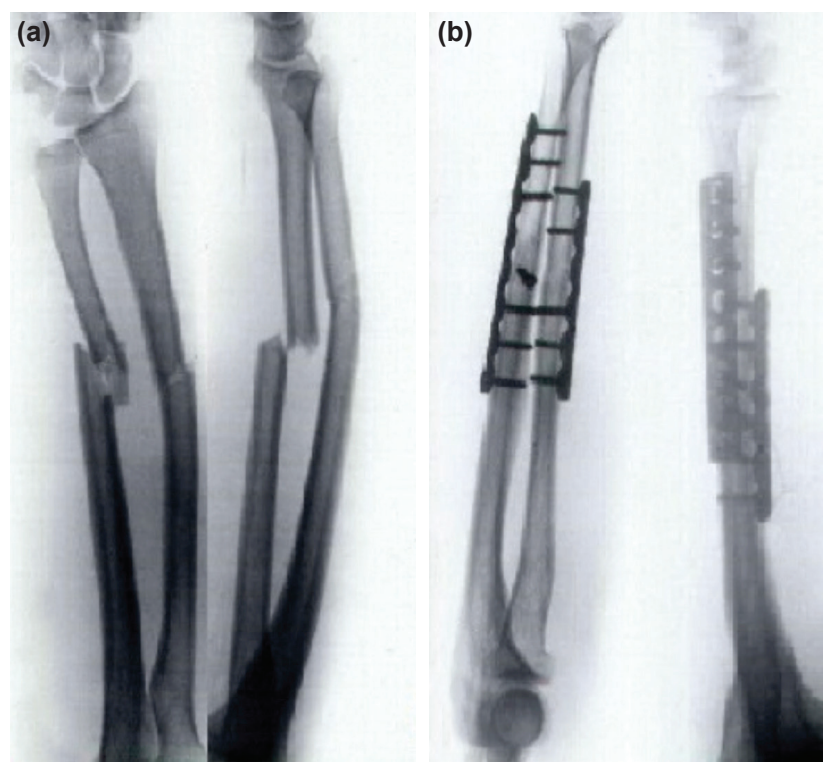

Figure 4. AP and lateral radiographs (a) Type 22B3 fracture on the right radius and ulna diaphysis belonging to a 40 -year-old male patient after a motor vehicle accident. The patient's $12^{\text {th }}$ month (b) direct radiographs. 


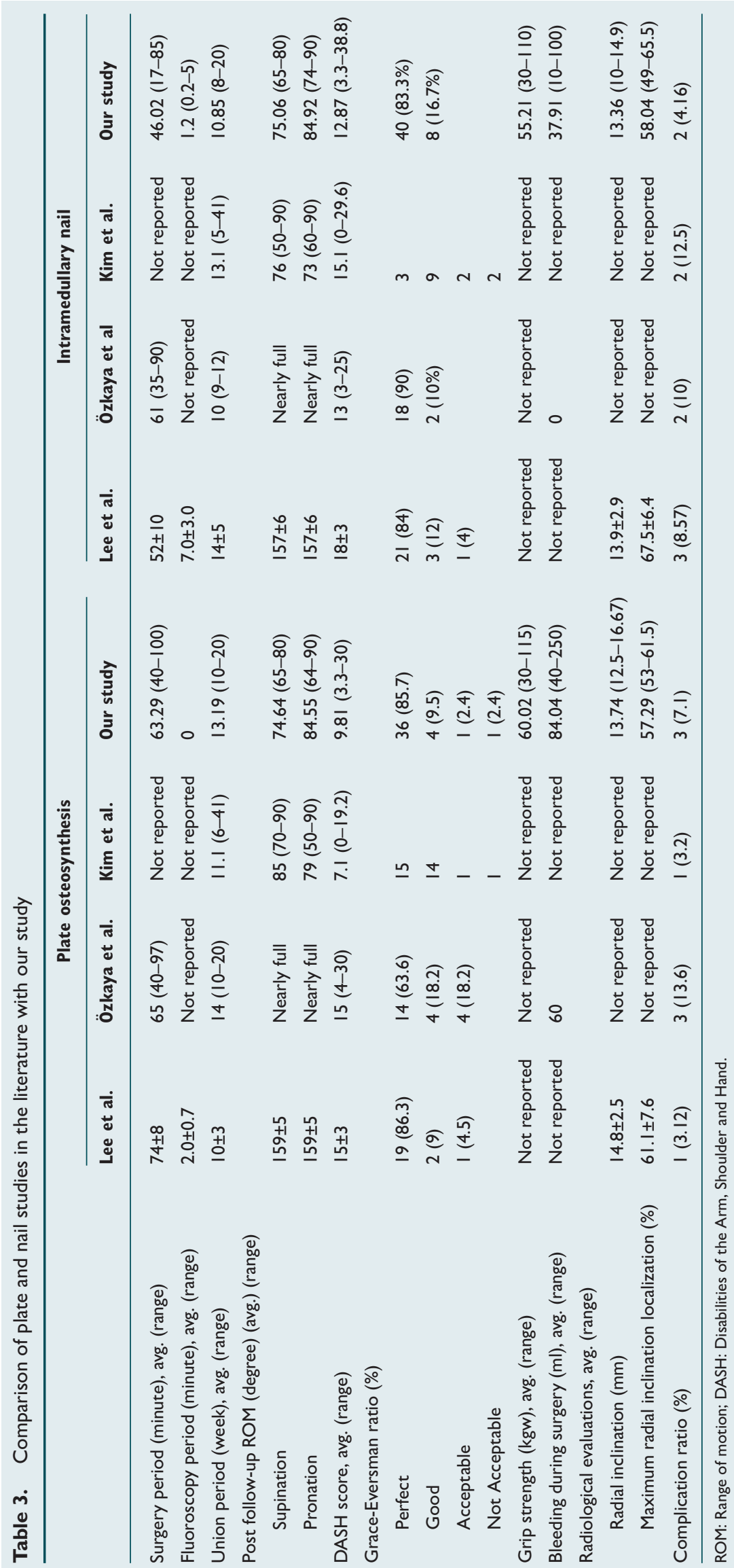

17-85) min in the IM nailing group. A statistically significant difference was determined between the groups $(p<0.05)$. The mean DASH score was 9.8I (range, 3.3-38) in the plate group and 12.87 (range, 3.3-38.8) in the IM nailing group. According to the GraceEversman criteria, results were excellent in $36(85.7 \%)$ patients, good in 4 $(9.5 \%)$, and acceptable in I (2.4\%) in the plate group and excellent in 40 (83.3\%) and good in $8(16.7 \%)$ patients in the IM nailing group (Tables 2,3$)$.

No statistically significant difference was determined between groups with respect to DASH score and GraceEversman evaluation criteria $(p>0.05)$. No difference was observed between groups with respect to the measurement of degree of supination and pronation and grip strength $(p>0.05$; Table 2). The mean MRI was 13.74 (range, 12.5-16.67) in the plate group and 13.36 (range, 10-14.49) in the IM nailing group, and the mean MRIL was 57.29 (range, 53-61.5) and 58.04 (range, 49-65.5), respectively. No statistically significant difference was determined between groups with respect to MRI and MRIL measurements ( $p>0.05)$. The mean amount of bleeding was 84.04 (range, 40-250) and 37.9I (range, 10100) $\mathrm{ml}$, respectively. The difference between groups was statistically significant ( $p<0.05$; Table 2$)$. The two groups were not significantly different in terms of fracture type, open fracture, wrist ROM, duration of hospitalization, and time spent until the time of surgery.

Fluoroscopy guidance was not used during plate application. The mean duration of fluoroscopy use during IM nailing application was 1.2 (range, I.2-5) $\mathrm{min}$. Changes were observed in operating time and fluoroscopy time together with the learning curve (Fig. 5).

No iatrogenic bone, tendon, vascular, or nerve damage developed in any patient in either group during the operation. Postoperative superficial infection developed in two patients in the plate group, which recovered with antibiotic therapy. In one patient, nonunion was 


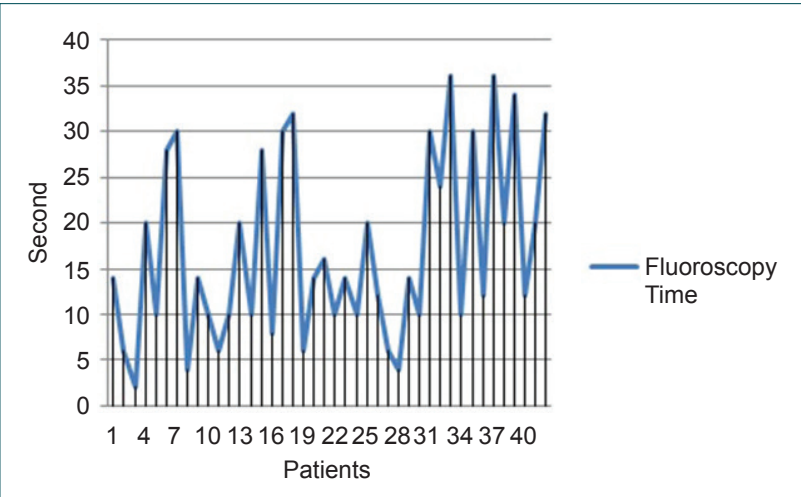

Figure 5. The learning curve and fluoroscopy time distribution based on patients.

observed in the postoperative month 8 , so autogenous bone graft taken from the iliac wing was applied with plate osteosynthesis. In the IM nailing group, in one patient, superficial infection was treated successfully with antibiotic therapy. In one patient at 4 months postoperatively, rupture of the extensor pollicis longus (EPL) tendon developed as a result of wear from the nail tip. Tendon repair was applied using an autograft from the ipsilateral palmaris longus. At the final follow-up examination, the patient had no subjective complaints.

No mechanical irritation, implant failure, synostosis, or compartment syndrome developed in any patient in either group. In four patients in each group, the implant was removed on patient request at mean 23 (range, 20-28) months. No refracture was observed in the follow-up period.

\section{DISCUSSION}

The current treatment for adult forearm diaphyseal fractures is surgery. The traditional surgical method is ORIF. ${ }^{[14]}$ Aspects of the method have been criticized, and there are complications. Therefore, it is not a standard treatment method. ${ }^{\left[{ }^{[8}\right.}$ The search for alternative methods to ORIF has been ongoing in the historical treatment process. Although IM implants have been attempted from time to time as an alternative treatment, due to poor results, this has not been used sufficiently. Intramedullary treatment was reported first in $1913^{[14]}$ using nonspecific materials (first generation) such as the K-wire, rush pin, and Steinmann nail. Sufficient rotational stability could not be achieved with these materials. Intramedullary treatment used as a support caused high rates of nonunion. The first nail design to take the forearm anatomy into account (second generation) was by Sage in 1959. ${ }^{[15]}$ The nail was designed with anatomic features than enabled it to maintain rotational stability. However, there were no locking or compression features. As fracture stability could not be achieved, additional fixation materials were required, and high rates of nonunion were seen; thus, IM implants did not find a place of sufficient use in treatment. Just as it is today, ORIF has always been an acceptable treatment method. However, this has not prevented researchers from developing new IM implants, which have been designed with anatomic and biomechanical analyses of the forearm bones as references (third generation), and very good clinical and radiological results have been obtained. The possibility of stronger rotational stability is provided with the anatomic design of third generation nails and the locking and compression effects. ${ }^{[16-19]}$

The basic aim of surgical treatment of forearm diaphyseal fractures is to provide stable axial and rotational fixation. To achieve excellent rotational results, the acceptable axial angulation must be $<10^{\circ} .{ }^{[3]}$ Even if radial bowing and the interosseous gap are fully restored, it has been reported that rotational functional results could be limited. ${ }^{[20]}$ Anatomic reduction is obtained with open reduction, which results in optimal repair of axial alignment, radial incline, and the interosseous gap. Forearm IM treatment differs from nail application in other long bones, as there are no anatomical landmarks providing guidance for rotational alignment.

In fluoroscopic imaging of rotational reduction, the continuity of the cortical distance in the distal and proximal areas of the fracture can be evaluated. There is little subcutaneous tissue support of the ulna. In IM treatment, axial and rotational alignment can be checked with palpation. However, in ORIF, it may be necessary to remove the implant because of mechanical irritation of the plate and screws. Greater soft tissue support in the radius makes correction of reduction and radial bowing more difficult. ${ }^{[21]}$ There are two curvatures in the coronal and sagittal planes of the radius. ${ }^{[22]}$ It is necessary to take these curvatures into account when preoperatively shaping the nails to appropriate IM anatomy. In the current study, the radius nails were parabola shaped. With a titanium elastic structure and the 3-point principle with parabolic shape, rotational stability was achieved. In addition, by conforming to the radial bowing, the optimal interosseous space was formed.

Few studies have compared ORIF and IM nailing treatment results in forearm diaphyseal fractures. These studies have compared, in particular, union status, time to union, and functional evaluation criteria. Anatomic or close to anatomic reduction is obtained with ORIF. Axial and rotational rigid, stable fixation is obtained. However, drainage of the fracture hematoma has negative effects on union, and it has been reported that excessive soft tissue and periosteal stripping could cause union problems. It is known that, as a result of the super periosteal pressure of conventional plates, osseous feeding is impaired, which has a negative effect on union. However, this risk is reduced with the LC-DCP plate. The risk of refracture is increased due to cortical atrophy, which develops in the screw application areas. It is necessary to apply immobilization, regardless of the stability of the fixation. Cosmetic problems may also develop associated with the surgical approach. ${ }^{[5-8]}$ Surgical intervention causes more bleeding. For the provision of open reduction, there is no fluoroscopy guidance 
and therefore no exposure to radiation. Despite the stated advantages and disadvantages of the method, union rates of 87\%-98\% are reported. ${ }^{[3,4,7,10,23-25,27]}$ Time to union has been reported as between 7.4 and 33 weeks. ${ }^{[23-27]}$ Functional evaluation results generally are at a satisfactory level. In the plate group of the current study, union was achieved at a rate of $97.6 \%$ at a mean of 13.19 (range, 10-20) weeks. Bleeding in the plate group was measured as mean 84.04 (range, 40-250) $\mathrm{ml}$. The mean operating time was 63.29 (range, 40-100) min. In one patient with nonunion, grafting from the iliac wing and plate osteosynthesis was applied. Union was achieved 6 months after the second operation. Intramedullary nailing causes less soft tissue damage in the surgical application and provides cosmetic superiority. The amount of bleeding during surgery is lower. Intramedullary implants generally have the property of stress distribution, and stronger callus tissue is formed. An important cosmetic advantage is that the implant can be removed from the same incision. Length is protected in segment forearm fractures. However, exposure to radiation is a significant disadvantage in IM nailing applications, and the immobilization period is shorter. Nailing treatment is contraindicated in patients with an open epiphysis line when there is active infection and in those with IM diameter $<3 \mathrm{~mm}$.

In IM applications, union rates of $94 \%-100 \%$ and time to union of 10 weeks to 4.4 months have been reported. [12,16,17,28] Good functional results have been reported similar to those of plate osteosynthesis. In the IM group of the current study, $100 \%$ union was obtained at a mean of 10.85 (range, 8-20) weeks. The amount of bleeding in the IM group was 37.9 ( range, 10-100) ml. The mean operating time was 46.02 (range, 17-85) min. A statistically significant difference was determined between groups with respect to time to union, amount of bleeding, and operating time. No statistically significant difference was determined with respect to radiological and functional results (Grace-Eversman criteria, DASH score, grip strength, MRI and MRIL values, and functional joint range of movement; Table 3). The shorter time to union of the IM method compared with that of ORIF could have been due to not draining the fracture hematoma and early mobilization. As the IM method is less invasive, the amount of bleeding is reduced. The stage of controlled exposure in ORIF was thought to have prolonged the operating time.

The areas of application of both treatment methods carry potential risks. In proximal radius diaphyseal fractures, the posterior interosseous nerve is at risk. ${ }^{[29]}$ There is a risk of damage in open reduction during surgical exposure and in IM treatment during locking. Careful surgical exposure in open reduction can reduce the risk to a minimum. In radius nails with proximal locking, the risk can be reduced to a minimum with locking made in a neutral position with the screw 3 $\mathrm{cm}$ distal to the radius head. ${ }^{[17]}$ latrogenic fracture may be caused by the use of a nail with a larger than normal diameter and rotational instability by the use of a small nail. In the area of nail application in the radius, the EPL and superficial branch of the radial nerve are at risk. ${ }^{[30,31]}$ In the current study, EPL tendon rupture developed in one patient at 4 months postoperatively as a result of friction from the nail tip. Tendon repair was made with palmaris longus autograft and at the final follow-up examination, the patient had no subjective complaints.

The removal after union of the internal fixation material used is controversial. In open or fragmented fractures or those that have resulted from high-energy trauma, when there is insufficient compression or reduction in fragmented fractures and when there is another fracture in the same extremity, the rate of refracture has been reported to increase. ${ }^{[32,33]}$ It has been reported that removal of the fixation material at 8 months postoperatively reduces the rate of refracture, ${ }^{[33]}$ and refracture could be observed at 2-24 months after implant removal. ${ }^{[32]}$ In the current study, implants were removed on patient request in 4 (9.5\%) of the plate group and 4 (8.3\%) of the IM group. No cases of refracture were observed during the follow-up period.

There were some limitations to this study, the most important of which are that the number of patients was low, and the study was retrospective. A non-standardized follow-up period is a general deficiency of retrospective studies. Furthermore, it is difficult to obtain simultaneous data. With the exception of the DASH score, all data are the findings of the 6-month follow-up examination. We aimed to standardize the radiological data by using data obtained from the evaluations at the same time point for all patients. The distribution of heterogeneous fracture bone type (isolated fractures and both bone fractures were included) is a significant limitation. The selections of treatment method and evaluation methodology cause conflict in retrospective evaluations. The treatment choice is explained by the routine treatment protocols of the surgeons. The patient evaluation forms created were routine data, independent of personal interpretation. Future prospective studies conducted on a greater number of patients in multiple centers, comparing homogenous fracture types would be able to make a greater contribution to the literature.

\section{Conclusion}

The current treatment method for adult forearm diaphyseal fractures is plate osteosynthesis. The results of the current study showed IM nailing treatment to be superior to ORIF with respect to operating time and time to union. However, no difference was determined between the two methods according to the functional evaluation criteria. Radiologically, plate osteosynthesis is superior in restoration of MRI and MRIL. However, a statistically significant relationship was not detected between supination and pronation with MRI and MRIL. Due to the shorter time to union, shorter operating time, and cosmetic advantages, IM nailing treatment can be 
considered a good alternative method to ORIF in the treatment of adult forearm diaphyseal fractures.

\section{Conflict of interest: None declared.}

\section{REFERENCES}

1. Crenshaw AH. Fractures of shoulder, arm and forearm. In: Canale ST, Daugherty K, Jones L, editors.Campbell's operative orthopaedics. 10. St. Louis: Mosby; 2003. p. 3049-58.

2. Markolf KL, Lamey D, Yang S, Meals R, Hotchkiss R. Radioulnar load-sharing in the forearm. A study in cadavera. J Bone Joint Surg Am 1998;80:879-88. [CrossRef]

3. Schemitsch EH, Richards RR. The effect of malunion on functional outcome after plate fixation of fractures of both bones of the forearm in adults. J Bone Joint Surg Am 1992;74:1068-78. [CrossRef]

4. Anderson LD, Sisk D, Tooms RE, Park WI 3rd. Compression-plate fixation in acute diaphyseal fractures of the radius and ulna.J Bone Joint Surg Am 1975;57:287-97. [CrossRef]

5. Kim SB, Heo YM, Yi JW, Lee JB, Lim BG. Shaft Fractures of Both Forearm Bones: The Outcomes of Surgical Treatment with Plating Only and Combined Plating and Intramedullary Nailing. Clin Orthop Surg 2015;7:282-90. [CrossRef]

6. Lee SK, Kim KJ, Lee JW, Choy WS. Plate osteosynthesis versus intramedullary nailing for both forearm bones fractures. Eur J Orthop Surg Traumatol 2014;24:769-76. [CrossRef]

7. Ozkaya U, Kiliç A, Ozdoğan U, Beng K, Kabukçuoğlu Y. Comparison between locked intramedullary nailing and plate osteosynthesis in the management of adult forearm fractures. Acta Orthop Traumatol Turc 2009;43:14-20. [CrossRef]

8. Behnke NM, Redjal HR, Nguyen VT, Zinar DM. Internal fixation of diaphyseal fractures of the forearm: a retrospective comparison of hybrid fixation versus dual plating. J Orthop Trauma 2012;26:611-6. [CrossRef]

9. AO Foundation [homepage on the Internet]. Web Services [cited 2008 Aug 10]. Boer PD, Rüedi T, Colton C, Raaymakers E, Schatzker J, Trafton P, editors. AO Surgery reference. Available from: http://www.aofoundation.org.

10. Grace TG, Eversmann WW Jr. Forearm fractures: treatment by rigid fixation with early motion.J Bone Joint Surg Am 1980;62:433-8. [CrossRef]

11. Hudak PL, Amadio PC, Bombardier C. Development of an upper extremity outcome measure: the DASH (disabilities of the arm, shoulder and hand) [corrected]. The Upper Extremity Collaborative Group (UECG). Am J Ind Med 1996;29:602-8. [CrossRef]

12. Köse A, Aydın A, Ezirmik N, Can CE, Topal M, Tipi T. Alternative treatment of forearm double fractures: new design intramedullary nail. Arch Orthop Trauma Surg 2014;134:1387-96. [CrossRef]

13. Gustilo RB, Anderson JT. Prevention of infection in the treatment of one thousand and twenty-five open fractures of long bones: retrospective and prospective analyses. J Bone Joint Surg Am 1976;58:453-8. [CrossRef]

14. Bartoníček J, Kozánek M, Jupiter JB. History of operative treatment of forearm diaphyseal fractures. J Hand Surg Am 2014;39:335-42. [CrossRef]

15. Sage FP. Medullary fixation of fractures of the forearm. A study of the medullary canal of the radius and a report of fifty fractures of the radius treated with a prebent triangular nail. J Bone Joint Surg Am 1959;41A:1489-516. [CrossRef]

16. Lee YH, Lee SK, Chung MS, Baek GH, Gong HS, Kim KH. Interlocking contoured intramedullary nail fixation for selected diaphyseal fractures of the forearm in adults. J Bone Joint Surg Am 2008;90:1891-8.

17. Köse A, Aydın A, Ezirmik N, Topal M, Can CE, Yllar S. Intramedullary nailing of adult isolated diaphyseal radius fractures. Ulus Travma Acil Cerrahi Derg 2016;22:184-91.

18. Weckbach A, Blattert TR, Weisser Ch. Interlocking nailing of forearm fractures. Arch Orthop Trauma Surg 2006;126:309-15. [CrossRef]

19. Köse A, Aydin A, Ezirmik N, Yildirim ÖS. Treatment of Ipsilateral Distal Humerus and Diaphyseal Ulna Fractures by Using an Olecranon Osteotomy and Intramedullary Nail. J Orthop Trauma 2016;30:251-5.

20. Tarr RR, Garfinkel AI, Sarmiento A. The effects of angular and rotational deformities of both bones of the forearm. An in vitro study. J Bone Joint Surg Am 1984;66:65-70. [CrossRef]

21. Bot AG, Doornberg JN, Lindenhovius AL, Ring D, Goslings JC, van Dijk $\mathrm{CN}$. Long-term outcomes of fractures of both bones of the forearm. J Bone Joint Surg Am 2011;93:527-32. [CrossRef]

22. Bartoníček J, Naňka O, Tuček M. Internal fixation of radial shaft fractures: Anatomical and biomechanical principles. [Article in Czech] Rozhl Chir 2015;94:425-36. [Abstract]

23. Stevens CT, ten Duis HJ. Plate osteosynthesis of simple forearm fractures: LCP versus DC plates. Acta Orthop Belg 2008;74:180-3.

24. Stern PJ, Drury WJ. Complications of plate fixation of forearm fractures. Clin Orthop Relat Res 1983;175:25-9. [CrossRef]

25. Leung F, Chow SP. A prospective, randomized trial comparing the limited contact dynamic compression plate with the point contact fixator for forearm fractures. J Bone Joint Surg Am 2003;85-A:2343-8. [CrossRef]

26. Jones DB Jr, Kakar S. Adult diaphyseal forearm fractures: intramedullary nail versus plate fixation. J Hand Surg Am 2011;36:1216-9. [CrossRef]

27. Droll KP, Perna P, Potter J, Harniman E, Schemitsch EH, McKee MD. Outcomes following plate fixation of fractures of both bones of the forearm in adults. J Bone Joint Surg Am 2007;89:2619-24. [CrossRef]

28. Köse A, Aydin A, Ezirmik N, Topal M, Can CE. Treatment of isolated ulnar fractures in adults with a new intramedullary nail. Minerva Ortopedica e Traumatologica 2015;66:123-31.

29. Tabor OB Jr, Bosse MJ, Sims SH, Kellam JF. Iatrogenic posterior interosseous nerve injury: is transosseous static locked nailing of the radius feasible? J Orthop Trauma 1995;9:427-9. [CrossRef]

30. Fanuele J, Blazar P. Extensor pollicis longus tendon rupture in an adult after intramedullary nailing of a radius fracture: case report. J Hand Surg Am 2009;34:627-9. [CrossRef]

31. Köse A, Aydın A, Köse M, Tipi T. Late rupture of extensor pollicis longus as a complication of treatment of forearm both bone fracture with the new intramedullary nail. Eur Orthop Traumatol 2015;6:273-6. [CrossRef]

32. Deluca PA, Lindsey RW, Ruwe PA. Refracture of bones of the forearm after the removal of compression plates. J Bone Joint Surg Am 1988;70:1372-6. [CrossRef]

33. Labosky DA, Cermak MB, Waggy CA. Forearm fracture plates: to remove or not to remove. J Hand Surg Am 1990;15:294-301. [CrossRef] 
ORİJINAL ÇALIŞMA - ÖZET

\section{Yetişkin önkol diafiz kırıklarında açık redüksiyon internal fiksasyon ve intramedüller çivi tedavi sonuçlarının karşılaştırılması \\ Dr. Ahmet Köse, ${ }^{1}$ Dr. Ali Aydın, ${ }^{2}$ Dr. Naci Ezirmik, ${ }^{2}$ Dr. Ömer Selim Yıldırım}

${ }^{1}$ Erzurum Bölge Eğitim ve Araştırma Hastanesi, Ortopedi Kliniği, Erzurum

${ }^{2}$ Atatürk Üniversitesi Tıp Fakültesi, Ortopedi ve Travmatoloji Anabilim Dalı, Erzurum

AMAÇ: Yetişkin önkol diafız kırığı (radius, ulna veya her iki kemik kırığı) olan hastalarda uyguladığımız intramedüller çivi tedavisi ile açık redüksiyon internal fiksasyon tedavi yöntemlerini kaynama ve fonksiyonel sonuçlar açısından karşılaştırmayı amaçladık.

GEREÇ VE YÖNTEM: Önkol diafız kırığı nedeniyle cerrahi tedavi uyguladığımız, iskelet sistemi matürasyonu tamamlanmış 90 hastayı geriye dönük olarak inceledik. Monteggia, Galeazzi, ipsilateral üst ekstremite fraktürü olan hastalar, epifiz hattı açık hastalar, Tip 3 açık kırı̆ıı olan hastalar, patolojik kırı̆ı olan hastalar ve beyin travması olan hastalar çalışmaya dahil edilmedi. Hastaların 42'sine açık redüksiyon internal fiksasyon (plak grubu), 48'ine intramedüller çivi tedavisi (IM çivi grubu) uygulandı. İki tedavi grubu; kaynama zamanı, eklem hareket açıklı̆ı, ameliyat süresi, kavrama gücü, GraceEversman kriterleri ve komplikasyon sonuçlarına göre karşılaştırıldı.

BULGULAR: Ameliyat süresi plak grubunda 63.29 (40-100) dakika, intramedüller çivi grubunda 46.02 (I7-85) dakika idi. Plak grubunda ortalama kaynama süresi I3.19 (I0-20) hafta, IM çivi grubunda ortalama I0.85 (8-20) hafta değerlendirildi. İstatistiksel olarak kaynama süresi ve ameliyat süreleri açısından her iki grup arasında anlamlı fark saptanırken Grace-Eversman değerlendirme kriterleri, önkol supinasyon, pronasyon dereceleri ve kavrama gücü açısından iki grup arasında fark saptanmadı.

TARTIŞMA: İntramedüller çivi tedavisinde kaynama süresi, ameliyat süresi ve kanama miktarı açısından açık redüksiyon internal fiksasyon tedavisine göre anlamlı fark saptandı. Ancak fonksiyonel değerlendirme kriterlerine göre fark saptanmamıştır. Bu nedenle iskelet sistemi matürasyonu tamamlanmış önkol diafız kırı̆̆ı olan erişkin hastalarda her iki tedavi metodu kabul edilebilir yöntemlerdir.

Anahtar sözcükler: Açık redüksiyon; internal fiksasyon; intramedüller çivi; önkol.

Ulus Travma Acil Cerrahi Derg 2017;23(3):235-244 doi: 10.5505/tjtes.2016.66267 